\title{
Problems and Functional Disabilities Among Patients with Cervical Disc and Relationship with Low Back Pain
}

\author{
Seham A. Abd El-Hay ${ }^{1 *} \quad$ Fatma Abbass Salem ${ }^{2} \quad$ Hoda Esmat Mahmoud Khalil ${ }^{3}$ \\ 1.Assistant professor, Medical \&Surgical Nursing, Faculty of Nursing, Tanta University, Egypt \\ 2.Lecturer, Medical \&Surgical Nursing, Faculty of Nursing, Tanta University, Egypt \\ 3. Lecturer, Community Health Nursing, Faculty of Applied Medical Science, Must University, Egypt
}

\begin{abstract}
Background: cervical disc disorder is associated with many problems and functional disabilities which affect quality of life for patients. Neck pain is as common as low back pain which are considered from associated problems with cervical disc. Aim: This study was conducted to assess problems and functional disabilities among patients with cervical disc and relationship with low back pain. Design and Setting: A descriptive exploratory correlational study design was used and data were collected from Physical Medicine and Rehabilitation Department and it's affiliated out patient clinic of Tanta Main University Hospital. Sample: Purposive sampling of (90) patients from previous mentioned setting during follow-up period. Tools: Three tools were used for data collection: Tool (I); Sociodemographic and Medical data of the patients, Tool (II); Neck Disability Index scale to examine the degree of disability resulted from cervical disc and its effect on daily activities. Tool (III); RolandMorris Low Back Pain and Disability Questionnaire to assess pain-related disability resulting from low back pain. Results: As a result of this study, the majority (66.7\%) of the patients had complete level of neck disability and $(82.2 \%)$ of them had high level of disability due to low back pain. Moreover the majority of the patients $(67.6 \%)$ had high level of disability due to low back pain associated with complete neck disability due to cervical disc. Significant positive correlation was noted between total score of neck disability index and total score of rolandmorrislow back pain and disability.Conclusion and Recommendation: These results indicate that majority of the patients had complete level of neck disability and high level of disability due to low back pain. Significant positive correlation was noted between total score of neck disability index and total score of roland-morrislow back pain and disability. Further research must be done in many settings to evaluate whether disability prevention or interventions can improve functional disabilities.
\end{abstract}

Keywords: Cervical disc, functional disability, Low Back Pain.

DOI: $10.7176 / \mathrm{JHMN} / 61-05$

Publication date: April $30^{\text {th }} 2019$

\section{Introduction}

Cervical disc affects up to two-thirds of the population in their life time. While often benign and episodic in nature, cervical disc may become debilitating resulting in severe pain either neck or low back pain and possibility neurologic sequelae (Todd 2011). Cervical disc accounts for up to $36 \%$ of all spinal intervertebral disc disease, second only to lumbar disc, which accounts for $62 \%$ of all spinal intervertebral disc disease. Cervical problems tend to be less debilitating than lumbar problems all over the world (Windsor\& Young 2018). Problems in the cervical part of spinal column are connected with neck, arm, forearm, low back pain which can significantly decrease patients' quality of life, this is due to pathological changes that are impacting cervical spinal nerves forming cervical and brachial plexuses (Kolenkiewicz etal, 2018). Low back pain also can result from various pathologies and in $90 \%$ of patients, the main causes are degenerative changes in the intervertebral discs (Chiba etal. 2017).

There are 23 total discs in the entire spinal column, and six of them are in the cervical spine which is separated by discs that are filled with a cushioning gel-like substance (Goolkasian etal, 2002). Cervical disc rests between the cervical vertebrae, acts as a shock absorber in the cervical spine, enables the neck to handle various loads, stabilize neck and allow it to turn smoothly from side to side and bend forward to back, without discs the spine would be very stiff during motion (Paul \& Slosar 2016). Cervical disc caused by an abnormality in one or more discs, the cushions that lie between the neck bones (vertebrae). When a disc is damaged due to any cause, it can lead to neck pain from inflammation or muscle spasm (Martin \& Web 2018; Chin etal., 2017).

A cervical disc disorder is defined as the cervical degenerative disc disease, it develops when one or more of the cushioning discs in the cervical spine start to break down due to wear and tear. It is diagnosed when a damaged disc in the spine becomes symptomatic (Furma \& Hommer 2018). The most common complaints for cervical disc include; neck pain, focal burning / numbness, tingling, or weakness in the arms or hands. Patients with radiculopathy have compression of a single or multiple nerve roots. Those with myelopathy is defined as cord compression, may experience these symptoms involving entire extremities (arms $/$ hands/legs); rarely they develop sphincter (bowel/bladder) dysfunction (Kim 2019; Epstein \& Hollingsworth 2017). Several studies suggested that a cervical disc may cause of low back pain and lower extremity symptoms. However, $35.4 \%$ of persons who 
reported having low back pain also reported having neck pain due to cervical disc that are supported its relationship (Green etal., 2001).

Low back pain affects about $60 \%$ to $80 \%$ of the adult population. Many studies documented that the causes of low back pain often are very difficult to determine, for up to $85 \%$ of patients, no specific cause can be found (Hart etal., 1995; Deyo \& Tsui-Wu 1987; Barr \& Harrast 2007). Low back pain is major health problems that are caused by variety of pathologies such as degenerative disc disease as cervical disc, annular tears, and loss of disc height or collapse which can result in abnormal motion of the segment and biomechanical instability causing pain (Pengel etal., 2003; Frelinghuysen etal., 2005). Low back pain is known to be associated with degeneration of the spinal motion segment. Degeneration is thought to initiate in the intervertebral disc with subsequent degeneration that are occurring in the facet joints (Katz 2006; Pereira etal., 2017). Although cervical disc degeneration occurs frequently with aging, and may be asymptomatic in most cases but in certain instances it can cause severe LBP (Edgar 2017; Balagué etal., 2012).

The first line of the management for cervical disc disease is evaluation of patients that are carried out with assessment of neurological symptoms (complaints) and signs (examination of neurological deficits) (Epstein \& Hollingsworth 2017). Physical therapy is a major treatment option for cervical disc in addition to medication to control pain. The therapist can use cervical traction to restore mobility through exercises and manipulation of the muscles to reduce pain, stiffness and correct postures to help for improving complaints especially low back pain (Kim 2019). If pain, numbness, tingling or weakness persists beyond six to eight weeks, surgery may be indicated (Gilbert 2019). It is very important that cervical disc patients take precautions regarding passive manipulation of the cervical spine because such forceful movement on the cervical spine can increase arm pain, numbness, weakness, with potentially catastrophic results (Gilbert 2019;Nadri \& Ramandi 2016; Yan etal., 2016).

Cervical neck pain and low back pain together could cause abstinence in competition and substantially affect patient's functional status which impede their quality of life (Farahbakhsh etal., 2018), and lead to physical impairments and psychosocial disturbance which are including pain, impairments in the cervical range of motion, low self-efficacy, depression, sickness-related absences were associated with neck disability and low back pain (Saavedra-Hernandez etal., 2012). Evaluating these functional disabilities that are associated with cervical disc and low back pain is a pressing demand in nursing management of patients with vertebral disorders or vertebral disfunctions in order to best manage injuries and prevent further disabilities (Farahbakhsh etal., 2018). Therefore the aim of this study was to assess problems and functional disabilities among patients with cervical disc and relationship with low back pain.

\section{Significance of the study}

Cervical disc disorders cause severe neck pain which are leading to weakness or numbness from shoulders down to arms and descending to cause back pain (Brannen 2018). Patient may experience low back pain due to several factors which is increased over time. Cervical disc and low back pain may be interferes with physical functional capacity, quality of life and leads to limitations of daily activities among patients which increased need for understanding long-term outcome in patients after cervical disc and its' association with low back pain in order to optimize the clinical interventions and enhance the epidemiological research in the future and permit for these patients to life without surgery.

\section{Aim of the study}

The study was conducted to assess problems and functional disabilities among patients with cervical disc and relationship with low back pain.

\section{Research questions}

To fulfill the aim of the study the following research questions were formulated

-what are the problem and functional disabilities experienced by patients with cervical disk?

-what are the problems experienced by patients during low back pain?

- What is the relationship between cervical disk and low back pain?

\section{Subjects and method \\ Research design}

A descriptive exploratory correlational study design was utilized to conduct this study

\section{Setting}

The study was conducted in the Physical Medicine and Rehabilitation Department and it's affiliated out patient Clinic of Tanta Main University Hospital. 


\section{Subjects}

Purposive sampling of (90) patients who are visiting the previous mentioned setting during follow-up period. The sample size was estimated by using Epi Info Software Statistical package created by World Health Organization and Center for Disease Control and Prevention, Atlanta, Georgia, USA version 2002 according to the following parameters; Total target population size $=400$ patients, confidence level $=99.9 \%$, expected frequency $=50 \%$, accepted error $=5 \%$ and confidence coefficient $=95 \%$. The acceptable sample size was 90 patients.

\section{Inclusion criteria for the patients}

-Both gender.

-Age ranged between 21-70 years.

-All patients were preoperative in the acute and chronic stage.

-Educated patients and able to drive.

\section{Exclusion criteria for the patients}

-Patients with decompensated liver cirrhosis, rheumatoid arthritis and osteoporosis.

- Post - operative cervical disck.

-Previous head trauma or stroke.

-Skeletal muscle deformity.

\section{Tools of data collections}

Three tools were used to collect data for this study. These tools aimed to assess problems and functional disabilities among patients with cervical disc and relationship with low back pain.

Tool (I): Sociodemographic and Medical data of the patients:-

It was comprised of two parts:-

Part (1): Socio-demographic characteristics of patients: which includes; patient' code, age, gender, marital status, occupation, educational level, place of residency, smoking.

Part (B): Patients' clinical data:-: It was developed by the researchers to assess patients' clinical data regarding; presence of neck pain, low back pain, headache, neck stiffness, numbness, upper limb weakness, burning sensation, stabbing sensation, disturbance of the balance, limping when walking, diabetes and hypertension. Scoring system: clinical data scored as the following; if the problem present scored (1) and if the problem absent scored (0).

Tool (II): Neck Disability Index scale (NDI):

Neck Disability Index scale was developed by Vernon \& Mior (1991). It was modified by the researchers according to literature reveiew (Macdermid etal., 2009; Stratford eta., 2009; Young 2010; Lucas hoving 2003). Neck Disability Index was designed to assess limitations of the cervical spine function during everyday activities. The NDI is comprised of 10 questions regarding: pain intensity, personal care, lifting, sleeping, driving, recreation, headache, concentration, reading and work, each item is expressed by 6 different assertions scored from 0-5, with 0 indicating no disability, 1 indicating mild disability, 2 indicating moderate disability, 3 indicating fairly severe disability, 4 indicating very disability and 5 indicating highest disability. Total scoring; ranged between $0-50$. The following guide used for interpretation of patients score: $0-4=$ no disability, $5-14=$ mild disability, $15-24=$ moderate disability, 25-34= severe disability and 35 or over= complete disability.

Tool (III): Roland-Morris Low Back Pain and Disability Questionnaire (RMQ):

Roland-Morris Low Back Pain and Disability Questionnaire was developed by (Roland \& Morris (1983; Stratford etal., 1996; Baker eta., 1989; Grotle etal., 2004; Lauridsen etal. 2006; Roland \& Fairbank 2000). The RMQ is comprised of 24-item patient-reported outcome measure that inquires about pain-related disability resulting from low back pain. The Roland-Morris Questionnaire (RMQ) is a self-administered disability measure in which greater levels of disability are reflected by higher numbers on a 24-point scale. The RMQ has been shown to yield reliable measurements, which are valid for inferring the level of disability, and to be sensitive to change over time for groups of patients with low back pain. Scoring system; Items are scored 0 if left blank or 1 if endorsed, for a total RMQ score ranging from 0 to 24 where zero (indicating no dis-ability) and 24 (indicating severe disability).

\section{Ethical consideration}

An official permission was obtained from the Head of the Physical Medicine and Rehabilitation Department and its affiliated Out patient Clinic of Tanta Main University Hospital. Informed consent was taken from every patient after clarifying the procedures and the purpose to participate in the study. They were informed about confidentiality of data collection, their right to refuse participation and to withdraw at any time without any consequences. A code number was used instead of name.

\section{Methods of data collection}

1 - Tools of the study were developed by the researchers after reviewing relevant literature and used to collect data 
except tool (II) Neck Disability Index scale was developed by Vernon \& Mior (1991) and tool (III) Roland-Morris Low Back Pain and Disability Questionnaire was developed by Roland and Morris (1983).

2-The tools were tested for its content validity by a jury of five experts in the area of Medical Surgical Nursing and Physical Medicine and Rehabilitation, Their opinions were elicited regarding tools format and consistency, it was calculated and found to be $=(98 \%)$. The reliability for the study tools was calculated by Cronbach's alpha test; it was 0.887 for tool (1) part B and 0.910 for tool (II) and 0.87 for tool (III).

3- A pilot study was carried out to test the study tools. It was conducted on $10 \%$ of the total sample size to test the feasibility and applicability of the tools, evaluate the research plan and to determine any obstacles that may encountered during the period of data collection, accordingly, needed modification was done. The pilot patients were excluded from the study sample.

4- All Tools of data collection were translated into Arabic language because the study subjects had different levels of education.

5- This study was conducted at the beginning of November 2018 to February 2019.

6- Procedure of data collection:-

-Patients were invited to participate in the research study at the morning shift while they were waiting physiotherapy session in the Physical Medicine and Rehabilitation Department and it's affiliated out patient clinic of Tanta Main University Hospital during follow up period. The researchers were contacted with each patient who arrived to clarify importance of the research and take consent.

-The data were collected from the patients in the special room, started by using tool (I): part (A) and (B) to collect baseline data and Tool II and Tool III to assess the degree of disability resulted from cervical disc pain and painrelated disability resulting from low back pain.

- Sheet was distributed on the attending patients, each of them was asked to complete assessment sheets and return them to the researchers in the same visiting.

-Instructions were provided to the patients about how the questions should be answered. Each question answered and a mark was allocated for each suitable answer. The researchers were available for any explanations and checking each questionnaire after the completion, to be sure that there were no missed items.

-The researchers were collected the questionnaire sheets personally at the end of time. Each participant was taking approximately 30 minutes to complete all sheets.

\section{Methods of data analysis}

All data were collected, coded, tabulated and subjected to statistical analysis. Statistical analysis is performed by statistical Package SPSS in general (version 20), also Microsoft office Excel is used for data handling and presentation. Descriptive statistics including frequency distribution, means and standard deviation, suitable statistical analysis was utilized: probability of errors was $\mathrm{p}<05$. 
Results:

Table (1): Distribution of the studied patients according to their socio-demographic Characteristics

\begin{tabular}{|c|c|c|}
\hline \multirow[t]{2}{*}{ Variables } & \multicolumn{2}{|c|}{$\begin{array}{c}\text { The studied subjects } \\
(\mathrm{N}=90)\end{array}$} \\
\hline & $\overline{\mathbf{N}}$ & $\%$ \\
\hline $\begin{array}{cc}\text { Age in years } \\
: & 30-\leq 40 \\
: & 41-\leq 50 \\
: & 50 \leq 60 \\
: & \geq 60-70\end{array}$ & $\begin{array}{c}26 \\
39 \\
19 \\
6\end{array}$ & $\begin{array}{c}28.9 \\
43.3 \\
21.1 \\
6.7\end{array}$ \\
\hline $\begin{aligned} & \underline{\text { Sex }} \\
& \text { - } \text { Male } \\
& \text { - Female }\end{aligned}$ & $\begin{array}{l}56 \\
34\end{array}$ & $\begin{array}{l}62.2 \\
37.8\end{array}$ \\
\hline $\begin{aligned} & \text { Marital status } \\
& \text { : } \text { Married } \\
& \text { : } \text { Single } \\
& \text {. } \text { Divorced } \\
&\end{aligned}$ & $\begin{array}{c}55 \\
2 \\
17 \\
16\end{array}$ & $\begin{array}{c}61.1 \\
2.2 \\
18.9 \\
17.8\end{array}$ \\
\hline $\begin{aligned} & \text { Occupation } \\
& \text { - } \text { Worker } \\
& \text { - } \text { Employee } \\
& \text { Not work } \\
&\end{aligned}$ & $\begin{array}{l}30 \\
38 \\
22 \\
\end{array}$ & $\begin{array}{l}33.3 \\
42.2 \\
24.4\end{array}$ \\
\hline $\begin{aligned} & \text { Level of education } \\
&: \text { Primary } \\
&: \text { Secondary education } \\
& \text { - } \text { University education }\end{aligned}$ & $\begin{array}{c}9 \\
42 \\
39\end{array}$ & $\begin{array}{l}10.0 \\
46.7 \\
43.3\end{array}$ \\
\hline $\begin{array}{c}\text { Place of residency } \\
: \quad \text { Village } \\
\text { City } \\
\end{array}$ & $\begin{array}{l}42 \\
48 \\
\end{array}$ & $\begin{array}{l}46.7 \\
53.3 \\
\end{array}$ \\
\hline $\begin{array}{r}\text { Smoking } \\
\quad \text { Yes } \\
\text { No }\end{array}$ & $\begin{array}{l}47 \\
43\end{array}$ & $\begin{array}{l}52.2 \\
47.8\end{array}$ \\
\hline
\end{tabular}

Table (1) showed the distribution of studied patients' relevant to their socio-demographic characteristics. As regards age, the table revealed that nearly half of the patients $(43.3 \%)$ were in the age group $(41-\leq 50)$ with and more than half of them (62.2\%) were male. Regarding marital status, the table revealed that about $(61.1 \%)$ of patients were married. As for occupation the majority of them (42.2\%) were employers. Also the majority of them (46.7 and $43.3 \%)$ were secondary and university educated respectively. Majority of patients $(53.3 \%)$ were from city and $(52.2 \%)$ were smokers.

Table (2): Distribution of the studied patients relevant to their medical data

\begin{tabular}{|c|c|c|}
\hline \multirow[t]{2}{*}{ Variables for the presence of problems } & \multicolumn{2}{|c|}{$\begin{array}{l}\text { The studied subjects } \\
(\mathrm{N}=90)\end{array}$} \\
\hline & $\mathbf{N}$ & $\%$ \\
\hline 1. Neck Pain & 84 & 93.3 \\
\hline 2. Low Back Pain & 75 & 83.3 \\
\hline 3. Headache & 55 & 61.1 \\
\hline 4. $\quad$ Neck Stiffness & 77 & 85.6 \\
\hline 5. Numbness & 79 & 87.8 \\
\hline 6. Upper Limb Weakness & 73 & 81.1 \\
\hline 7. Burning Sensation & 52 & 57.8 \\
\hline 8. Stabbing Sensation & 74 & 82.2 \\
\hline 9. Aches & 74 & 82.2 \\
\hline 10. Disturbance of balance & 48 & 53.3 \\
\hline 11. Limping when walking & 31 & 34.4 \\
\hline 12. Diabetes & 68 & 75.6 \\
\hline 13. Hypertension & 75 & 83.3 \\
\hline
\end{tabular}


Table (2): Showed the distribution of the studied patients relevent to their clinical data. The table showed that the majority of patients $(93.3,87.8,85.6,83.3,83.3,82.2,82.2$ and $81.1 \%$ ) had neck pain , numbness, neck stiffness, low back pain, hypertension, stabbing sensation, aches, and upper limb weakness respectively. In addition to more than half $(75.6,61.1,57.8$ and $53.3 \%)$ of them suffered from; diabetes, headache, burning sensations and disturbance of balance respectively.

Table (3): Part (A); Distribution of the studied patients according to their level of Neck Disability.

\begin{tabular}{|c|c|c|c|c|c|c|c|c|c|c|}
\hline \multirow{3}{*}{$\begin{array}{l}\text { Variables of limitations to cervical spine } \\
\text { function }\end{array}$} & \multicolumn{10}{|c|}{$\begin{array}{l}\text { The studied patients } \\
(\mathrm{N}=90)\end{array}$} \\
\hline & \multicolumn{2}{|c|}{$\begin{array}{c}\text { Mild } \\
\text { disability } \\
\text { (2) }\end{array}$} & \multicolumn{2}{|c|}{$\begin{array}{c}\text { Moderate } \\
\text { disability } \\
\text { (3) }\end{array}$} & \multicolumn{2}{|c|}{$\begin{array}{c}\text { Fairly } \\
\text { severe } \\
\text { disability } \\
(4)\end{array}$} & \multicolumn{2}{|c|}{$\begin{array}{c}\text { Very } \\
\text { severe } \\
\text { disability } \\
(5)\end{array}$} & \multicolumn{2}{|c|}{$\begin{array}{c}\begin{array}{c}\text { Highest } \\
\text { disability }\end{array} \\
\text { (6) }\end{array}$} \\
\hline & $\mathbf{N}$ & $\%$ & $\mathbf{N}$ & $\%$ & $\mathbf{N}$ & $\%$ & $\mathbf{N}$ & $\%$ & $\mathbf{N}$ & $\%$ \\
\hline Section 1: Pain Intensity & 5 & 5.6 & 28 & 31.1 & 37 & 41.1 & 20 & 22.2 & & \\
\hline $\begin{array}{l}\text { Section 2: Personal Care (Washing, } \\
\text { Dressing) }\end{array}$ & 12 & 13.3 & 33 & 36.7 & 31 & 34.4 & 14 & 15.6 & - & - \\
\hline Section 3: Lifting & 1 & 1.1 & 35 & 38.9 & 48 & 53.3 & 6 & 6.7 & - & - \\
\hline Section 4: Reading & 2 & 2.2 & 36 & 40.0 & 40 & 44.4 & 9 & 10.0 & 3 & 3.4 \\
\hline Section 5: Headaches & 10 & 11.1 & 40 & 44.4 & 34 & 37.8 & 6 & 6.7 & - & - \\
\hline Section 6: Concentration & 6 & 6.7 & 44 & 48.9 & 31 & 34.4 & 9 & $\mathbf{1 0 . 0}$ & - & - \\
\hline Section 7: Work & 7 & 7.8 & 18 & 20.0 & 36 & 40.0 & 28 & 31.1 & 1 & 1.1 \\
\hline Section 8: Driving & 2 & 2.2 & 20 & 22.2 & 55 & 61.1 & 12 & 13.3 & 1 & 1.1 \\
\hline Section 9: Sleeping & 7 & 7.8 & 22 & 32.2 & 43 & 40.0 & 17 & 18.9 & 1 & 1.1 \\
\hline Section 10: Recreation & 14 & 15.6 & 21 & 23.3 & 33 & 36.7 & 20 & 22.2 & 2 & 2.2 \\
\hline
\end{tabular}

PART B: Total level of neck disability index scale among studied patients

\begin{tabular}{|c|c|c|c|}
\hline \multirow[t]{2}{*}{ Total Level of Neck Disability } & \multicolumn{2}{|c|}{$\begin{array}{c}\text { The studied subjects } \\
(\mathrm{N}=90)\end{array}$} & $\begin{array}{c}\chi^{2} \\
P\end{array}$ \\
\hline & $\mathbf{N}$ & $\%$ & \multirow{4}{*}{$\begin{array}{l}50.889 \\
0.000 * *\end{array}$} \\
\hline Severe disability & 30 & 33.3 & \\
\hline Complete disability (over 35) & 60 & 66.7 & \\
\hline $\begin{array}{l}\text { Range } \\
\text { Mean } \pm \text { SD }\end{array}$ & \multicolumn{2}{|c|}{$\begin{array}{c}25-49 \\
36.766 \pm 4.439\end{array}$} & \\
\hline
\end{tabular}

*Significant $\mathbf{P}<\mathbf{0 . 0 5}$

Table (3): Part (A); Showed the distribution of the studied patients according to their level of neck disability. Regarding to pain intensity the table showed that the majority of the patients $(41.1 \%)$ suffering from fairly severe disability with pain. For about lifting more than half of studied patients $(53.3 \%)$ had fairly severe disability to lift anything. Also the table revealed that the near to half patients $(48.9 \%)$ had moderate disability regarding concentration. For about driving, the table showed that the majority of the patients $(61.1 \%)$ had fairly severe disability .

Part B: showed the total level of neck disability index scale among studied patients. The table showed that $(66.7 \%)$ of the patients had complete level of neck disability. Whereas $(33.3 \%)$ of them had severe level of neck disability with highly significant $\mathrm{p}$ value $\mathrm{P}<0.05$ 
Table (4): Part A. Distribution of the studied patients according to their level of low back pain related disability

\begin{tabular}{|c|c|c|}
\hline \multirow[b]{2}{*}{ Disabilities related to low back pain } & \multicolumn{2}{|c|}{$\begin{array}{l}\text { The studied subjects } \\
\qquad(\mathrm{N}=90)\end{array}$} \\
\hline & $\mathbf{N}$ & $\%$ \\
\hline 1- I stay at home most of the time because of my back. & 69 & 76.7 \\
\hline 2- I change position frequently to try to get my back comfortable. & 75 & 83.3 \\
\hline 3- I walk more slowly than usual because of my back. & 75 & 83.3 \\
\hline $\begin{array}{l}\text { 4- Because of my back, I am not doing any jobs that I usually do around the } \\
\text { house. }\end{array}$ & 62 & 68.9 \\
\hline 5- Because of my back, I use a handrail to get upstairs. & 55 & 61.1 \\
\hline 6- Because of my back, I lie down to rest more often. & 71 & 78.9 \\
\hline $\begin{array}{l}\text { 7- Because of my back, I have to hold on to something to get out of an easy } \\
\text { chair. }\end{array}$ & 76 & 84.4 \\
\hline 8-Because of my back, I try to get other people to do things for me. & 60 & 66.7 \\
\hline 9- I get dressed more slowly than usual because of my back. & 60 & 66.7 \\
\hline 10- I only stand up for short periods because of my back. & 76 & 84.4 \\
\hline 11- Because of my back, I try not to bend or kneel down. & 69 & 76.7 \\
\hline 12- I find it difficult to get out of a chair because of my back. & 72 & 80.0 \\
\hline 13- My back is painful almost all of the time. & 60 & 66.7 \\
\hline 14- I find it difficult to turn over in bed because of my back. & 69 & 76.7 \\
\hline 15- My appetite is not very good because of my back. & 73 & 81.1 \\
\hline $\begin{array}{l}\text { 16- I have trouble putting on my socks (or stockings) because of the pain in } \\
\text { my back. }\end{array}$ & 67 & 74.4 \\
\hline 17- I can only walk short distances because of my back pain. & 66 & 73.3 \\
\hline 18- I sleep less well because of my back. & 66 & 73.3 \\
\hline 19- Because of my back pain, I get dressed with the help of someone else. & 58 & 64.4 \\
\hline 20- I sit down for most of the day because of my back. & 70 & 77.8 \\
\hline 21- I avoid heavy jobs around the house because of my back. & 77 & 85.6 \\
\hline $\begin{array}{l}\text { 22- Because of back pain, I am more irritable and bad tempered with people } \\
\text { than usual. }\end{array}$ & 71 & 78.9 \\
\hline 23- Because of my back, I go upstairs more slowly than usual. & 77 & 85.6 \\
\hline 24- I stay in bed most of the time because of my back. & 63 & $\mathbf{7 0 . 0}$ \\
\hline Total Mean \pm SD & & \\
\hline
\end{tabular}

Part B : Total level of low back pain related disability among studied Patients

\begin{tabular}{|c|c|c|c|}
\hline \multirow[t]{2}{*}{ Total Levels Of Low Back Pain Related Disability } & \multicolumn{2}{|c|}{$\begin{array}{l}\text { The studied subjects } \\
(\mathrm{N}=90)\end{array}$} & $\begin{array}{l}\chi^{2} \\
\mathbf{P}\end{array}$ \\
\hline & $\mathbf{N}$ & $\%$ & \multirow{3}{*}{$\begin{array}{l}33.733 \\
0.000 * *\end{array}$} \\
\hline Low level of disability due to LBP $\quad(<60 \%)$ & 16 & $\mathbf{1 7 . 8}$ & \\
\hline High level of disability due to LBP $\quad(>60 \%)$ & 74 & 82.2 & \\
\hline $\begin{array}{l}\text { Range } \\
\text { Mean } \pm \text { SD }\end{array}$ & & & \\
\hline
\end{tabular}

* Significant at $\mathbf{P}<\mathbf{0 . 0 5}$.

Table (4): Part A; Showed the distribution of the studied patients according to their levels of low back pain related disability. The table showed that the majority of the patients (go up stairs more slowly than usual, avoid heavy jobs around the house, avoid heavy jobs around the house, only stand up for short periods, have to hold on to something to get out of an easy chair, change position frequently to be comfortable, walk more slowly, appetite is not very good, find it difficult to get out of a chair, lie down to rest more often, and more irritable and bad tempered with people than usual as following; $(85.6,85.6,84.4,84.4,83.3,83.3,81.1,80,78.9$, and $78.9 \%$ ) respectively.

Part B ; Showed the total levels of low back pain and disability among studied patients . The table showed that majority $(82.2 \%)$ of the patients had high level of disability due to low back pain, whereas $(17.8 \%)$ of the patients had had low level of disability due to low back pain with highly significant value at $\mathrm{P}<0.05$. 
Table (5): Relationship between patients' total level of neck disability and total level of low back pain related disability.

\begin{tabular}{|c|c|c|c|c|c|c|c|}
\hline \multirow[t]{2}{*}{ Variables } & \multicolumn{2}{|c|}{$\begin{array}{c}\text { Low level of } \\
\text { disability due to low } \\
\text { back pain } \\
(n=16)\end{array}$} & \multicolumn{2}{|c|}{$\begin{array}{c}\text { High level of } \\
\text { disability due to } \\
\text { low back pain } \\
(n=74)\end{array}$} & \multicolumn{2}{|c|}{$\begin{array}{c}\text { Total } \\
(\mathbf{N}=90)\end{array}$} & $\overline{\mathbf{P}}$ \\
\hline & $\mathbf{N}$ & $\%$ & $\mathbf{N}$ & $\%$ & $\mathbf{N}$ & $\%$ & \multirow{3}{*}{0.772} \\
\hline $\begin{array}{ll}\text { - } & \text { Severe disability }\end{array}$ & 6 & 37.5 & 24 & 32.4 & 30 & 33.3 & \\
\hline - Complete disability & 10 & 62.5 & 50 & 67.6 & 60 & 66.7 & \\
\hline
\end{tabular}

Table (5): showed the relationship between patients' total level of neck disability and total level of low back pain related disability. The table revealed that the majority of the patients $(67.6 \%)$ had high level of disability due to low back pain associated with complete neck disability due to cervical disc with not significant difference.

Table (6): Relationship between socio-demographic characteristics of the studied patients and their level of neck disability.

\begin{tabular}{|c|c|c|c|c|c|}
\hline \multirow{3}{*}{ Variables } & \multicolumn{5}{|c|}{$\begin{array}{l}\text { The studied subjects } \\
(\mathrm{N}=90)\end{array}$} \\
\hline & \multicolumn{2}{|c|}{$\begin{array}{c}\text { Severe disability } \\
(30)\end{array}$} & \multicolumn{2}{|c|}{$\begin{array}{c}\text { Complete disability } \\
(60)\end{array}$} & \multirow{2}{*}{$\begin{array}{l}\chi^{2} \\
\mathbf{P}\end{array}$} \\
\hline & $\mathbf{N}$ & $\%$ & $\mathbf{N}$ & $\%$ & \\
\hline $\begin{array}{cc}\text { Age in years } \\
\cdot \quad 30-\leq 40 \\
: \quad 41-\leq 50 \\
=\quad 50 \leq 60 \\
=\quad \geq 60-70\end{array}$ & $\begin{array}{c}13 \\
12 \\
5 \\
0\end{array}$ & $\begin{array}{c}14.4 \\
13.3 \\
5.6 \\
0.0\end{array}$ & $\begin{array}{c}13 \\
27 \\
14 \\
6\end{array}$ & $\begin{array}{c}14.4 \\
30.0 \\
15.6 \\
6.7 \\
\end{array}$ & $\begin{array}{c}7.786 \\
0.021 *\end{array}$ \\
\hline $\begin{aligned} & \underline{\text { Sex }} \\
& \text { - } \text { Male } \\
& \text { - } \text { Female } \\
&\end{aligned}$ & $\begin{array}{l}20 \\
10\end{array}$ & $\begin{array}{l}22.2 \\
11.1\end{array}$ & $\begin{array}{l}27 \\
33\end{array}$ & $\begin{array}{l}30.0 \\
36.7\end{array}$ & $\begin{array}{l}3.763 \\
0.052\end{array}$ \\
\hline $\begin{array}{cl}\text { Marital status } \\
\text { - } & \text { Married } \\
\text { - } & \text { Single } \\
\text { - } & \text { Divorced } \\
\text { - } & \text { Widow }\end{array}$ & $\begin{array}{c}20 \\
1 \\
7 \\
2\end{array}$ & $\begin{array}{l}22.2 \\
1.1 \\
7.8 \\
2.2\end{array}$ & $\begin{array}{c}35 \\
1 \\
10 \\
14\end{array}$ & $\begin{array}{c}38.9 \\
1.1 \\
11.1 \\
15.6\end{array}$ & $\begin{array}{l}4.073 \\
0.254\end{array}$ \\
\hline $\begin{array}{cl}\text { Occupation } \\
\text { - } & \text { Worker } \\
\text { - Employee } & \text { Not work }\end{array}$ & $\begin{array}{c}8 \\
16 \\
6\end{array}$ & $\begin{array}{c}8.9 \\
17.8 \\
6.7\end{array}$ & $\begin{array}{l}22 \\
22 \\
16\end{array}$ & $\begin{array}{l}24.4 \\
24.4 \\
17.8\end{array}$ & $\begin{array}{l}2.279 \\
0.320\end{array}$ \\
\hline $\begin{aligned} & \text { Level of education } \\
& \text { - } \text { Primary } \\
& \text { - } \text { Secondary education } \\
& \text { - } \text { University education }\end{aligned}$ & $\begin{array}{c}6 \\
9 \\
15\end{array}$ & $\begin{array}{c}6.7 \\
10.0 \\
16.7\end{array}$ & $\begin{array}{c}3 \\
33 \\
24\end{array}$ & $\begin{array}{c}3.3 \\
36.7 \\
26.7\end{array}$ & $\begin{array}{l}7.640 \\
0.022 *\end{array}$ \\
\hline $\begin{array}{c}\text { Place of residency } \\
\text { - Village } \\
\text { - City }\end{array}$ & $\begin{array}{l}16 \\
14\end{array}$ & $\begin{array}{l}17.8 \\
15.6\end{array}$ & $\begin{array}{l}26 \\
34\end{array}$ & $\begin{array}{l}28.9 \\
37.8\end{array}$ & $\begin{array}{l}0.804 \\
0.370\end{array}$ \\
\hline
\end{tabular}

* Significant at $\mathbf{P}<\mathbf{0 . 0 5}$.

Table (6): showed the relationship between socio-demographic characteristics of the studied patients and their level of neck disability. The table showed that there was significant relationship between age and educational level and level of neck disability at $\mathrm{P}<0.05$. whereas there was no significant relationship between sex, marital status, occupation, place of residency and level of neck disability. 
Table (7): Relationship between socio-demographic characteristics of the studied patients and their level of low back pain and disability.

\begin{tabular}{||c|c|c|c|c|c|}
\hline \multirow{2}{*}{ Variables } & \multicolumn{5}{|c|}{ The studied subjects } \\
(N=90)
\end{tabular}

\footnotetext{
* Significant at $\mathbf{P}<\mathbf{0 . 0 5}$.
}

Table (7): showed the relationship between socio-demographic characteristics of the studied patients and their level of low back pain and disability. The table showed that there was significant relationship between age and level of low back pain and disability at $\mathrm{P}<0.05$. whereas there was no significant relationship between sex, marital status, occupation, educational level, place of residency and level of low back pain and disability. 
Table (8): Correlation between total score of neck disability and total score low back pain and disability and socio-demographic characteristics of the studied patients.

\begin{tabular}{|c|c|c|c|c|c|c|c|c|c|}
\hline \multirow{2}{*}{ Variables } & Age & Gender & $\begin{array}{c}\text { Marital } \\
\text { status }\end{array}$ & Occupation & $\begin{array}{c}\text { Level of } \\
\text { education }\end{array}$ & Residence & Smoking & $\begin{array}{c}\text { Total } \\
\text { score of } \\
\text { tool II }\end{array}$ & $\begin{array}{c}\text { Total } \\
\text { score of } \\
\text { tool III }\end{array}$ \\
\hline & $\begin{array}{l}\mathbf{r} \\
\mathbf{p}\end{array}$ & $\begin{array}{l}\mathbf{r} \\
\mathbf{p}\end{array}$ & $\begin{array}{l}\mathbf{r} \\
\mathbf{p}\end{array}$ & $\begin{array}{l}\mathbf{r} \\
\mathbf{p}\end{array}$ & $\begin{array}{l}\mathbf{r} \\
\mathbf{p}\end{array}$ & $\begin{array}{l}\mathbf{r} \\
\mathbf{p}\end{array}$ & $\begin{array}{l}\mathbf{r} \\
\mathbf{p}\end{array}$ & $\begin{array}{l}\mathbf{r} \\
\mathbf{p}\end{array}$ & $\begin{array}{l}\mathbf{r} \\
\mathbf{p}\end{array}$ \\
\hline Age & - & \begin{tabular}{|l|}
-0.214 \\
$0.043 *$
\end{tabular} & $\begin{array}{c}0.304 \\
0.004 * *\end{array}$ & $\begin{array}{l}0.007 \\
0.944\end{array}$ & $\begin{array}{c}-0.130 \\
0.220\end{array}$ & $\begin{array}{c}-0.042 \\
0.691\end{array}$ & $\begin{array}{c}-\mathbf{0 . 3 7 0} \\
0.000 * *\end{array}$ & $\begin{array}{c}0.461 \\
0.000 * *\end{array}$ & $\begin{array}{c}0.269 \\
0.010 *\end{array}$ \\
\hline Gender & & - & $\begin{array}{c}-0.401 \\
0.000 * *\end{array}$ & $\begin{array}{c}0.496 \\
0.000 * *\end{array}$ & $\begin{array}{c}-0.183 \\
0.085\end{array}$ & $\begin{array}{c}-0.086 \\
0.419\end{array}$ & $\begin{array}{c}0.745 \\
0.000 * *\end{array}$ & $\begin{array}{l}0.025 \\
0.812\end{array}$ & $\begin{array}{l}0.014 \\
0.894\end{array}$ \\
\hline $\begin{array}{c}\text { Marital } \\
\text { status }\end{array}$ & & & - & $\begin{array}{c}-0.186 \\
0.079\end{array}$ & $\begin{array}{l}0.014 \\
0.896\end{array}$ & $\begin{array}{c}-0.051 \\
0.634\end{array}$ & $\begin{array}{c}-0.378 \\
0.000 * *\end{array}$ & $\begin{array}{l}0.200 \\
0.059\end{array}$ & $\begin{array}{l}0.090 \\
0.399\end{array}$ \\
\hline Occupation & & & & - & $\begin{array}{l}0.015 \\
0.888\end{array}$ & $\begin{array}{l}0.126 \\
0.237\end{array}$ & $\begin{array}{c}0.424 \\
0.000 * *\end{array}$ & $\begin{array}{c}-0.056 \\
0.599\end{array}$ & $\begin{array}{c}-0.078 \\
0.466\end{array}$ \\
\hline $\begin{array}{l}\text { Level of } \\
\text { education }\end{array}$ & & & & & - & $\begin{array}{c}0.240 \\
0.023 *\end{array}$ & $\begin{array}{c}-0.059 \\
0.582\end{array}$ & $\begin{array}{l}0.050 \\
0.637\end{array}$ & $\begin{array}{c}-0.138 \\
0.194\end{array}$ \\
\hline Residence & & & & & & - & $\begin{array}{c}-0.178 \\
0.094\end{array}$ & $\begin{array}{l}0.021 \\
0.843\end{array}$ & $\begin{array}{l}\text { 0.007 } \\
0.947\end{array}$ \\
\hline Smoking & & & & & & & - & $\begin{array}{c}-0.015 \\
0.887\end{array}$ & $\begin{array}{c}-0.130 \\
0.223\end{array}$ \\
\hline $\begin{array}{c}\text { Total score of } \\
\text { tool II }\end{array}$ & & & & & & & & - & $\begin{array}{c}0.238 \\
0.024 *\end{array}$ \\
\hline $\begin{array}{c}\text { Total score of } \\
\text { tool III }\end{array}$ & & & & & & & & & - \\
\hline
\end{tabular}

* Significant $P<0.05$

** Highly significant at $\mathbf{P}<\mathbf{0 . 0 1}$

Table (8): showed the correlation between total score of neck disability and total score of low back pain and disability and socio-demographic characteristics of the studied patients. The table showed that there was a significant correlation between age and gender, marital status, smoking, total score of neck disability index scale and total score of back pain and disability where $\mathrm{p}=\mathrm{P}<0.05$ and $<0.01$. While there was a high significant positive correlation between total score of neck disability and total score of low back pain and disability where $\mathrm{p}=\mathrm{P}<$ 0.05 and $<0.01$.

\section{Discussion}

Cervical disc often results in neck pain for affected patients as a result of direct impingement of nerve roots and associated inflammatory processes (Carette \& Fehlings 2005). Disc provides stability and allowing a relatively wide range of motion in all directions in the neck and low back. When a disc starts to lose its strength and pliability, however, it can cause a range of painful and potentially debilitating symptoms (Stephen \& Falatyn 2018). This study aimed to assess problems and functional disabilities among patients with cervical disc and relationship with low back pain.

Concerning to socio-demographic data of the patients, the study results revealed that the majority of patients were in the age group $(41-\leq 50)$ years / old and more than half of them were male. For about marital status, the findings revealed that majority of patients were married and nearly half of them were employers, also the majority of them were secondary and university educated in addition to nearly half of them were from city and smokers. These results were in the same line with Bremerich etal., (2008; Clair \& Edmondston 2009) who mentioned that in their study about neck pain, the mean age for the study was relatively young (39 years) in comparison with other validity studies, where the mean age of patients ranged from 38 to 65 years and majority of the sample were female

Also this result was supported by Karl and Cshane (2001) who mentioned that in their study about disability in patients with cervical disorders, the majorty of the patient were in the age group (41-50) years old but the majority of study sample were female and also they are workers. Moreover, this result in the same line with Nadri and Fasih (2016) who reported that about (55.4\%) of the study subjects was male with mean age $38.2 \pm 6.6$. In addition to Adedoyin etal., (2004) who mentioned that in their study about neck pain as a result of cervical disc, the age range of the study subjects that participated was between 21 and 68 years/ old and this is consistent with 
the age range of patients affected by neck pain in most epidemiological studies

Regarding to medical data of the patients, the study finding showed that the majority of patients had neck and low back pain and suffered from; headache, neck stiffness, numbness, upper limb weakness, burning and stabbing sensation, aches, disturbance of balance and limping when walking and had history of diabetes and hypertension. These results were in the same line with Hansson and Jensen (2004) who reported that the most frequent complaints of patients with cervical disorders are neck pain, headache, burning senation, numbness as common as low back pain. Also Elowitz (2018) mentioned that patients with cervical (neck) disc suffered from neck pain that radiates down the arms to the hands, muscle spasms numbness, tingling, or weakness in the arms, hands, or fingers, balance problems and arm or leg weakness, cramping.

Regarding to level of neck disability, the finding of the study revealed that the majority of the patients suffered from fairly severe pain and, feel problem with lift anything, also had moderate problem regarding headache and concentration. For about work, driving, sleeping and recreation also the majority of the patients had fairly severe problem. Moreover the finding revealed that more than half of the patients had complete level of neck disability with highly significant $\mathrm{p}$ value $\mathrm{P}<0.05$. This results may be attributed to when disc is injured due to any cause, it can lead to severe neck pain due to inflammation or muscle spasm and without normal discs the spine would be very stiff during motion which affect any acivity for the patients.

These results were in the same line with Blozik etal., (2009) Who reported that the severity of cervical neck pain and the related disability can affect daily social and functional activities of the patients, ability to lift any thing, driving and reading, which may even also involve emotional and psychological aspects. Also Croft etal., (2009) reported that the physical factors that are associated with neck pain included heavy lifting, turning head during driving viewing television, carrying things and dressing, static work posture, vibrations, repetitive jobs and a high work pace.

Furthermore Leak etal., (1994) mentioned that cervical neck pain affect the main functional activities of the patients as; using phone, looking up to search things and daily work, sleep, lack of ability to concentrate, focus and feelings of anxiety. On the other hand this result was in contrast with Eftekhar etal., (2013)who mentioned that about $53.5 \%$ and $44.2 \%$ of the patients had mild and moderate disability index where they have more pain when sitting, standing and lifting, traveling and social life are difficult for resulted from neck pain, respectively.

Concerning to level of low back pain related disability. The finding of the study revealed that the majority of the patients (go up stairs more slowly than usual, avoid heavy jobs around the house, avoid heavy jobs around the house, only stand up for short periods, have to hold on to something to get out of an easy chair, change position frequently to be comfortable, walk more slowly, appetite is not very good, find it difficult to get out of a chair, lie down to rest more often, and more irritable and bad tempered with people than usual) . These results may be attributed to low back pain-related disability affects different aspects of daily life and provokes mental suffering which lead to decrease ability of the patients to keep up their professional activities and tend to take distance from social contact and avoid leisure activities.

Moreover more than three quarter of the patients had high level of disability related to low back pain with highly significant $\mathrm{p}$ value $\mathrm{P}<0.05$. These results were in the same line with Iorio etal., (2007) who reported that study sample of low back pain had more disability in shopping, taking a bath, doing the laundry, doing heavy household chores, cutting toenails, and carrying a shopping bag compared with participants who did not report frequent low back pain. Also Walsh etal., (2008) reported that the majority of participants experience moderate to severe disability due to low back pain, a high level inspected when compared to studies that evaluated disability in workers with musculoskeletal disorders.

In addition to Reid etal.,(2005) who mentioned that low back pain (LBP) had a negative impact on the functional status and working ability in the young and adult population. Also Kose \& Hatipoglu (2012) reported that patients with low back pain experience physical disabilities due to pain. Their daily living activities such as weight lifting, self-care, and walking for the surgical treatment group and social life, sleeping, sitting, and standing are affected by these disabilities and the intensity of pain affects the level of disability. Moreover Ilyas \& Dharmaji (2012) mentioned that about $74.4 \%$ and $25.6 \%$ of the studied dentists had mild to moderate disability index resulted from Low back pain which affect their ability to perform their work.

Concerning to the relationship between patients' total level of neck disability and total level of low back pain and disability. The finding of the study result revealed that majority of the patients had high level of disability due to low back pain associated with complete neck disability due to cervical disc. This result was in contrast with Guez etal., (2002) who reported that neck-related pain among population has been reported to be as high as $67 \%$ with up to $54 \%$ of the associated with low back pain. Also Iorio etal.,(2007) reported that the association between low back pain and neck pain disability was substantially weakened and no longer statistically significant when the results of performance-based tests are introduced in the models. Moreover, Misterska etal.,(2017) reported that low back pain -related disability coexists with restrictions experienced due to neck pain.

Regarding to the relationaships between sociodemographic characteristics of the studied patients and their low back pain related disability and their level of neck disability. This study showed significant relationship 
between age, educational level and level of neck disability where as there was no significant relationship between sex, marital status, occupation, place of residency and level of neck diability and low back diability. On other hand, there were significant relationship between age and level of low back pain and disability.

These results were in the same line with Nadri and Fasih (2016) who reported that there was no significant difference in the relationship between the prevalence of LBP and neck pain with sex, marital status and work habits, also LBP founded in $40 \%$ of patients and classified as severely disabling. In addition, severe neck pain had the highest percentage (46.5\%). Also Fejer and Hartvigsen (2008) who reported that there was moderate relationship between neck pain, low back pain intensity and disability were seen in all socio-demographic variables

Moreover Paul etal., (2016) reported that there were significant relation among occupations or activities of daily living Roland Morris Disability scores where patient need to decrease activity to achieve a functional state. Also Vigatto etal., (2007) reported that the mean neck disability index score observed indicates moderate disability, similar to findings in a study of a population with CLBP. Also Fejer and Hartvigsen (2008) who reported that relation between neck and low back pain and disability were moderate and increased with an increasing factors related to consequences of NP as sociodemographic charactersitics.

Regarding to correlation between total score of neck disability and total score of low back pain related disability and socio-demographic characteristics of the patients. The result showed that there was a significant correlation between age, gender, marital status, smoking, total score of neck disability and total score of low back pain and disability. While there was a high significant positive correlation between total score of neck disability and total score of low back pain related disability,there were in the same line with Misterska etal.,(2017) who reported that there were significant intercorrelations were found between cervical disc neck and lower back painrelated disability.

Moreover Emily etal.,(2011) mentioned that Correlations were found with pain, disability and driving task scores patients but duration of symptoms, age and gender did not have a significant association with NDI scores. Also Misterska etal.,(2017) who reported that significant correlation was discovered between the level of education and NDI total score. Moreover, the level of education was found to be associated with pain severity, social interaction and disability. In addition to Yue and Liu (2012) found a positive correlation between the duration of occupational sitting and occurrence of neck pain and low back pain. In contrast Fejer and Hartvigsen (2008) there was weak association between total level of neck and total level of low back pain duration and disability which indicates that pain duration is a poor indicator of the level of disability.

\section{Conclusion}

Based on the findings of the present study, it can be concluded that:

- The majority of the cervical disc patients had complete level of neck disability with highly significant $p$ value. Also more than three quarter of the patients had high level of disability due to low back pain with highly significant $\mathrm{p}$ value $\mathrm{P}<0.05$.

- The majority of the patients had high level of disability due to low back pain associated with complete neck disability due to cervical disc.

- High significant positive correlation were noted between total score of neck disability index scale and total score of roland-morrislow back pain and disability questionnaire.

\section{Recommendations}

Based on the finding of the present study, the researchers recommended:

- Further research must be done to evaluate whether disability prevention or reduction interventions can minimize this problem, improving these patients' functionality.

- Clinical guideline strategies must be designed for cervical disc patients and included in the routine hospital care to help to manage of spine disabilities.

- Furthermore, a deeper understanding of the dimensions of suffering and how it influences functional disability may be used to optimize treatment.

\section{Limitations of this study:}

The limitations of this study were decreased sample size who achieve inclusion criteria of the research as educated patients and able to drive which increase time for data collection.

\section{Reference}

Adedoyin, R., Idowu, B., Adagunodo, R., Owoyomi, A., \& Idowu, P., (2004), Musculoskeletal Pain Associated with the Use of Computer systems in Nigeria. International Journal of pain, symptoms control and Palliative care, 13, 125-130.

Baker, J., Pynsent, P., \& Fairbank, J., (1989), The Oswestry disability index revisited: its reliability, repeatability and validity, and a comparison with the St. Thomas's disability index. In: Roland MO, Jenner 
JR (Eds). Back Pain: New Approaches to Rehabilitation and Education. New York: Manchester University Press, 174-86.

Balagué, F., Mannion, A., \& Pellisé, F., (2012), Non-specific low back pain. Lancet. 379(9814), 482-91.

Barr, K., \& Harrast, M., (2007), Low back pain. In: Braddom RL, Buschbacher RM, Chan L. Physical Medicine and Rehabilitation. 3rd ed. Philadelphia: WB Saunders Company, 883-929.

Blozik, E., Laptinskaya, D., Herrmann-Lingen, C., Schaefer, H., Kochen, M., \& Himmel, W., (2009), Depression and anxiety as major determinants of neck pain: A cross-sectional study in general practice. BMC Musculoskelet Disord, 10,13.

Brannen, D., (2018), Winning disability benefits for neck and cervical disorders, resolute legal, https://www.resolutelegal.ca/blog/winning-disability-benefits-neck-disorders.

Bremerich, F., Grob, D., Dvorak, J., \& Mannion, A., (2008), The neck pain and disability scale: cross-cultural adaptation into German and evaluation of its psychometric properties in chronic neck pain and $\mathrm{C} 1-2$ fusion patients. Spine, 33(9), 1018-1027

Carette, S., \& Fehlings, M., (2005), Clinical practice. Cervical radiculopathy. N Engl J Med, 353, 392-99.

Chiba, D., Wada, K., \& Tanaka, T., (2017), Serum pentosidine concentration is associated with radiographic severity of lumbar spondylosis in a general Japanese population. Journal of Bone and Mineral Metabolism, 35(1), 65-72.

Chin, K., Pencle, F., Seale, J., \& Pencle, F., (2017), Clinical Outcomes of Outpatient Cervical Total Disc Replacement Compared With Outpatient Anterior Cervical Discectomy and Fusion. Spine,15(10), 567-574.

Clair, D., \& Edmondston, S., (2009), Validity of the Neck Disability Index and Neck Pain and Disability Scale for measuring disability associated with chronic, non-traumatic neck pain. Man Ther, 14(4), 433-438

Croft, P., Lewis, M., Papageorgiou, A., Thomas, E., Jayson, M., \& Macfarlane, G., (2001), Risk factors for neck pain: A longitudinal study in the general population. Pain, 93,317-25.

Deyo, R., \& Tsui-Wu, Y., (1987), Descriptive epidemiology of low-back pain and its related medical care in the United States. Spine, 12, 264-268.

Edgar, M., (2007), The nerve supply of the lumbar intervertebral disc. J Bone Joint Surg Br 89, 1135 - 9. 10.

Eftekhar Sadat, B., \& Babaei-Ghazani, A., (2013), Prevalence and risk factors of neck and shoulder pain in medical students of Tabriz University of Medical Sciences. Medical Journal of Tabriz University of Medical Sciences and Health Services, 35(3),12-7.

Elowitz, E., (2018), Herniated Disc, Department of Neurological Surgery, New York-Presbyterian Hospital/Weill Cornell Medical Center, http:// weillcornellbrain andspine.org/ condition/ herniated-disc/symptomsherniated-disc

Emily, R., \& Howell, B., (2011), The association between neck pain, the Neck Disability Index and cervical ranges of motion: a narrative review, J. Can Chiropr Assoc., 55(3).

Epstein, N., and Hollingsworth, R., (2017), Nursing review section of surgical neurology international : Evaluation of cervical disc disease and when surgery is warranted, Surgical Neurology International Published by Wolters Kluwer - Medknow, 8,136.

Farahbakhsh, F., Akbari-Fakhrabadi, M., Shariat, A., Cleland, J., Farahbakhsh, F., Seif-Barghi, T., Mansournia, M., and Rostami, M., (2018), Neck pain and low back pain in relation to functional disability in different sport activities, J Exerc Rehabil, 14(3), 509-515.

Fejer, R., \& Hartvigsen, J., (2008), Neck pain and disability due to neck pain: what is the relation?, Eur Spine J., $17,80-88$.

Furma M. \& Hommer D. (2018), Cervical Disc Disease, https://emedicine. medscape. com/article/ -overview.

Frelinghuysen, P., Huang, R., \& Girardi, F., (2005), Lumbar total disc replacement part I: rationale, biomechanics, and implant types. Orthop Clin North Am, 36, 293-299.

Gilbert, A., (2019), cervical disc herniation (neck), https://www.sonoranspine.com/article-layout/98-conditionsand-treatments/cervical-spine-neck/1352-cervical-disc-herniation-neck, Sonoran Spine Research and Education Foundation.

Goolkasian, P., Wheeler, A., Pietrobon, R., Coeytaux, R., \& Carey, T., (2002), Standard scales for measurement of functional outcome for cervical pain or dysfunction: A systematic review. Spine, 27, 515-22.

Green, W., DeHaven, K., \& Pfeffer, G., (2001), Low back pain Essentials of Musculoskeletal Care. $2^{\text {nd }}$ ed. Rosemont, IL: American Academy of Orthopaedic Surgeons, 553-555. Grotle, M., Brox, J., \& Vollestad, N., (2004), Concurrent Comparison of responsiveness in pain and functional status measurements used for patients with low back pain. Spine, 29(21), 492-501.

Guez, M., Hildingsson, C., \& Nilsson, M., (2002), The prevalence of neck pain: a population based study from Northern Sweden. Acta Orthop Scand., 73, 455-459.

Hansson, T., \& Jensen, I., (2004), Swedish council on technology assessment in health care (SBU). Chapter 6. Sickness absence due to back and neck disorders. Scand J Public Health Suppl, 63,109-51.

Hart, L., Deyo, R., \& Cherkin, D., (1995), Physician office visits for low back pain: frequency, clinical evaluation, 
and treatment patterns from a U.S. national survey. Spine, 20,11-19.

Hermann, K., \& Reese, S., (2001), Relationships among Selected Measures of Impairment, Functional Limitation, and Disability in Patients with Cervical Spine Disorders, Physical Therapy, 81. (3), 903

Ilyas, M., \& Dharmaji, T., (2012), Low back pain inDentists of Indonesia. Pakistan Oral \& Dental Journal 2012; 32(3):464-8

Iorio, A., Abate, M., Jack, M., Guralnik, M., Bandinelli, S., Cecchi, F., Cherubini, A., Corsonello, A., Foschini, N., Guglielmi, M., Lauretani, F., Volpato, S., Abate, G., \& Ferrucci, L., (2007)), from chronic low back pain to disability, a multifactorial mediated pathwayspine, 15, 32(26), 9-815.

Katz, J., (2006), Lumbar disc disorders and low-back pain: socioeconomic factors and consequences. J Bone Joint Surg Am., 88 (2), 21 - 4.

Kim, K., (2019), Cervical Disc Disease and Neck Pain, What Every Adult Should Know About Pain From Cervical Discs, https://www.webmd.com/pain-management/features/neck-pain, Web Med. University of California at Davis.

Kolenkiewicz, M., Włodarczyk, A., \& Wojtkiewicz, J., (2018), Diagnosis and Incidence of Spondylosis and Cervical Disc Disorders in the University Clinical Hospital in Olsztyn, Biomed Res Int., 3839.

Kose, G., \& Hatipoglu, S,. (2012), The effect of low back pain on the daily activities of patients with lumbar disc herniation: a Turkish military hospital experience. J. Neurosci Nurs. 44(2),98-104.

Lauridsen, H., Hartvigsen, J., Manniche, C., Korsholm, L., \& Grunnet-Nilsson, N., (2006), Responsiveness and minimal clinically important difference for pain and disability instruments in low back patients. BMC Musculosk Disorders, 7, 82.

Leak, A., Cooper, J., Dyer, S., \& Frank, A., (1994), The northwick park neck pain questionnaire devised tto measure neck pain and disability. Br. J. Rheumatol, 33, 469-74.

Lucas hoving, J., Elizabeth F., Niere, K. , \& Buchbinder, R., (2003), Validity of the neck disability index, Northwick park neck pain questionnaire, and problem elicitation technique for measuring disability associated with whiplash-associated disorders, pain, 102(3), 273-281.

Macdermid, J., Walton, D., Avery, S., Blanchard, A., McAlpine, C., \& Goldsmith, C., (2009), Measurement properties of the neck disability index a sustematic review Journal of Orthopedic and Sports Physical Therapy, 39(5), 400-17.

Martin, L., \& Web, M., (2018). Cervical Disc Surgery: Disc Replacement or Fusion?, https://www.webmd.com/back-pain/surgery-disc-replacement-fusion

Misterska, E., Gøowacki, J., Okręt, A., Laurentowska, M., \& Gøowack, M., (2017), Back and neck pain and function in females with adolescent idiopathic scoliosis: A followup at least 23 years after conservative treatment with a Milwaukee brace, 12 (12), 11.

Nadri, H., \& Ramandi, F., (2016), Low back and neck pain intensity and relationship with disability index among dentists, JOHE, Autumn, 5 (4), 218-225.

Paul, J., \& Slosar, M., (2016), Cervical Discs, spine health, https://www.spine-health. com/ conditions/ spineanatomy/cervical-discs.

Paul, W., Stratford, P., Daniel, L., \& Rddle, P., (2016), A Roland Morris Disability Questionnaire Target Value to Distinguish between Functional and Dysfunctional States in People with Low Back Pain, Physiotherapy Canada, 68(1), 29-35.

Pengel, L., Herbert, R., \&Maher, C., (2003), Acute low back pain: systematic review of its prognosis. BMJ, 327 , 323

Pereira, G., Roios, E., \& Pereira, M., (2017), Functional disability in patients with low back pain: the mediator role of suffering and beliefs about pain control in patients receiving physical and chiropractic treatment, Braz J Phys Ther., 21(6), 465-472.

Reid, M., Williams, C., \& Gill, T., (2005), Back pain and decline in lower extremity physical function among community-dwelling older persons. J Gerontol A Biol Sci Med Sci., 60,793-7.

Roland, M., \& Morris, R., (1983), Study of the natural history of back pain. Spine, 8(2),141-4.

Stratford, P., Binkley, J., Solomon, P., Finch, E., Gill, C., \& Moreland, J., (1996), Defining the minimum level of detectable change for the Roland-Morris questionnaire. Phys Ther. ,76(4),359-65, 66-8.

Roland, M., \& Fairbank, J., (2000), The Roland-Morris Disability Questionnaire and the Oswestry Disability Questionnaire. Spine, 25(24), 3115-3124

Saavedra-Hernandez, M., Castro-Sanchez, A., Cuesta-Vargas, A., Cleland, J., Fernandez-de-las-Penas, C., and Arroyo-Morales, M., (2012), The contribution of previous episodes of pain, pain intensity, physical impairment, and pain-related fear to disability in patients with chronic mechanical neck pain. Am J Phys Med Rehabil,91,1070-1076.

Stephen, P., \& Falatyn, M., (2018), All about Spinal Disc Problems, spine health, https://www.spinehealth.com/conditions/spine-anatomy/all-about-spinal-disc-problems,

Stratford, P., Riddle, D., \& Binkley, J., (2009), Using the neck disability index to make decisions concerning 
individual patients Physiotherapy Canada, 2, 107-112.

Todd, A., (2011), Cervical spine: degenerative conditions, Curr Rev Musculoskeletal Medical, 4(4), $168-174$.

Vernon, H., \& Mior, S., (1991), The Neck Disability Index: A study of reliability and validity. Journal of Manipulative and Physiological Therapeutics, 14, 409-415

Vigatto, R., Alexandre, N., \& Correa Filho, H., (2007), Development of a Brazilian Portuguese version of the Oswestry Disability Index: cross-cultural adaptation, reliability and validity. Spine. 32(4), 481-6.

Walsh, I., Oishi, J., \& Coury, H., (2008), Clinical and functional aspects of work-related musculoskeletal disorders among active workers. Rev Saúde Pública, 42(1),108-16.

Windsor, R., \& Young, C., (2018), Cervical Discogenic Pain Syndrome, https:// emedicine. medscape. com/ article/93761-overview, Medscape.

Yan, H., Guohua, L., Ren, S., and Johansen, D., (2016), "Mid- To Long-Term Outcomes of Cervical Disc Arthroplasty versus Anterior Cervical Discectomy and Fusion for Treatment of Symptomatic Cervical Disc Disease: A Systematic Review and Meta-Analysis of Eight Prospective Randomized Controlled Trials, 11 (2), 149312.

Young, I., Cleland, J., Michener, L., \& Brown, C., (2010), Reliability, Construct Validity, and Responsiveness of the Neck Disability Index, Patient-Specific Functional Scale, and Numeric Pain Rating Scale in Patients with Cervical Radiculopathy, American Journal of Physical Medicine \& Rehabilitation, 89(10), 831-839.

Yue, P., Liu, F., \& Li, L., (2012), Neck/shoulder pain and low back pain among school teachers in China, prevalence and risk factors. BMC Public Health, 1,789. 